\title{
Green Synthesis of Silver Nanoparticles Using Leaf Extract of Rosmarinus officinalis and Its Effect on Tomato and Wheat Plants
}

\author{
Fatma Aly Farghaly ${ }^{1} \&$ Nivien Allam Nafady ${ }^{1}$ \\ ${ }^{1}$ Botany and Microbiology Department, Faculty of Science, Assiut University, Assuit, Egypt \\ Correspondence: Fatma Aly Farghaly, Botany and Microbiology Department, Faculty of Science, Assiut \\ University, Assuit 71516, Egypt. Tel: 20-88-214-6423. E-mail: fatmaadel2003@yahoo.com
}

Received: August 19, 2015

Accepted: September 15, 2015 Online Published: October 15, 2015

doi:10.5539/jas.v7n11p277

URL: http://dx.doi.org/10.5539/jas.v7n11p277

\begin{abstract}
Biological green synthesis of silver nanoparticles (AgNPs) from silver salts is a growing advanced approach to avoid the requirement of costly instruments and involvement of hazardous chemicals as well. However, increasing use of AgNPs raises potential toxicity level in the environment. In this investigation, leaf extract of rosemary (Rosmarinus officinalis) used as a reducing and stabilizing agent for biosynthesis of AgNPs. The biosynthesized AgNPs were authorized by UV-vis spectrophotometer and X-ray diffraction (XRD) analysis. The shape and size of the biosynthesized AgNPs were studied using high resolution transmission electron microscope (TEM). The toxicity of the biosynthesized silver nanoparticles on wheat and tomato plants was studied by soaking wheat grains and tomato seeds in $100 \mathrm{mg} / \mathrm{L} \mathrm{AgNPs} \mathrm{and} \mathrm{follow} \mathrm{its} \mathrm{effect} \mathrm{on} \mathrm{seedling} \mathrm{growth} \mathrm{of} \mathrm{wheat} \mathrm{(at}$ 10 days) and on vegetative growth of tomato and wheat plants (at 35 days). Some physiological parameters as germination percentage of wheat seedling, length of seedling, dry weight, pigment fractions (chl.a, chl.b and caroteinoids), soluble proteins, lipid peroxidation (MDA) and antioxidant enzymes (catalase and peroxidase) of two plants were measured. AgNPs has a non-significant inhibitory effect on germination percentage of wheat, dry weight and pigment fractions. The biosynthesized AgNPs has a noticeable stress effect on tomato plant as reduced chlorophyll a and dry weight. Generally, AgNPs stimulate MDA accumulation in tomato and wheat plants. There was a noticeable different effect of AgNPs on soluble proteins and antioxidant enzymes as catalase and peroxidase among tomato and wheat plants.
\end{abstract}

Keywords: biosynthesis, rosemary, silver nanoparticles, tomato, toxicity, wheat

\section{Introduction}

Metal nanoparticles were widely used in different application with the rapid growth of nanotechnology. Silver nanoparticles (AgNPs) widely used in antimicrobial activity, cosmetics industry and daily products. Synthesis method of nanoparticles plays an important role in its technological advancement as it is the primary step to tune their physical, electronic, and optical properties of the synthesized nanoparticles by varying size, shape and surface chemistry (Sharma et al., 2009).

Recently, biological methods using microorganism, plant extract, and enzymes have proved itself an easy, cost-effective and eco-friendly alternative synthesis route of metallic nanoparticle compared to conventional procedures (Mittal et al., 2013; Tamuly et al., 2013). Among different biological routes developed so far, synthesis methods using either plant extract or fruit extract have several advantages over others as it does not require any cell culture and the process can easily be scaled up for large scale synthesis.

There are growing concerns over the potential adverse impacts of nanoparticles in the environment (Yin et al., 2012). AgNPs released into environment during their synthesis, incorporation of AgNPs into other goods, and recycling or disposal of these goods and AgNPs, of which may be intentional or accidental resulting in toxic effects to organisms (Thuesombat et al., 2014). Current annual global production of NPs was in the order of 103 tons in 2004, which is expected to increase further to 104-105 tons/year after 2010.

In plants, nanoparticles are adsorbed to plant surfaces and taken up through natural nano or micrometer scale plant openings. Further, when growing, plants absorb relatively large amounts of essential and non-essential elements, which at certain concentration may be toxic. Once stored within the plants, beneficial or toxic elements can be transferred along the food chain to consumers. 
The unique properties of nanoparticles may cause unexpected biological effects, such as toxicity. In higher plants, different and conflicting effects of AgNPs have been reported, depending on the intrinsic AgNPs properties (size and shape, aggregation state, and surface coatings), experimental system, plant species and developmental stage (Remédios et al., 2012). Mahmoodzadeh et al. (2013) reported that direct exposure to specific types of nanoparticles causes significant phytotoxicity, emphasizes the need for ecologically responsible disposal of wastes containing nanoparticles and also highlights the necessity for further study on the impacts of nanoparticles on agricultural and environmental systems. The toxicity of AgNPs has been investigated in different terrestrial and aquatic organisms and was found to be related to their bioaccumulation effect of silver (Georgios \& Sotiris, 2010).

It has been suggested that the toxicity of AgNPs is due to the release of $\mathrm{Ag}^{+}$(Piccapeitra et al., 2012). Results of Ag nanoparticles impaired the stages of cell division and caused cell disintegration (Yin et al., 2012).

Due to their physiochemical properties AgNPs can act as catalyst and produce reactive oxygen species, ROS, (Choi et al., 2008). The formation of free radicals on the surface of AgNPs has been observed (Kim et al., 2007). Other possible mechanisms for toxicity have been suggested to be interaction of thiol-groups that are part of important proteins; enzymes that are involved in cellular respiration and ion transport (Levard et al., 2012).

Some data on root phytotoxicity of $\mathrm{ZnO}$ and other nanoparticles are available (Lin \& Xing, 2008). On the contrary, some plants, such as Brassica juncea and Medicago sativa were shown to be able to form and to take up silver nanoparticles into their tissues (Harris et al., 2008). Since metabolic nanoparticles were widely used as a rapid growth of nanotechnology and for the concern about the action of AgNPs as a phytotoxicity agent and may be has a desired effect environment, our goal in this investigation aimed to evaluate the effect of rosemary biosynthesized silver nanoparticles on germination percentage and seedling growth of wheat and vegetative growth of wheat and tomato plants to detect its mode of action either its positive or negative action. The response of some enzymatic activities of both plant were taken into our consideration.

\section{Materials and Methods}

\subsection{Preparation of Rosemary Extract}

Leaves of rosemary (Rosmarinus officinalis) were collected, washed several times with sterilized distilled water. Five grams of fresh leaves were boiled in $100 \mathrm{~mL}$ distilled water for $5 \mathrm{~min}$. The solution left to cool, and then filtered with Whatman filter paper. Filtrate was centrifuged for $5 \mathrm{~min}$. at $4000 \mathrm{rpm}$. The supernatant was used for the synthesis of silver nanoparticles.

\subsection{Biosynthesis of Silver Nanoparticles}

The silver nitrate $\left(\mathrm{AgNO}_{3}\right)$ was purchased from Sigma-Aldrich Chemicals. Aqueous solution of $\mathrm{AgNO}_{3}(1 \mathrm{mM})$ was added drop wise into $50 \mathrm{~mL}$ of rosemary leaf extract. The mixture was incubated for $18 \mathrm{~h}$ at room temperature. Control without $\mathrm{AgNO}_{3}$ was also kept at the same conditions. The solution was centrifuged for $10 \mathrm{~min}$. at 10000 $\mathrm{rpm}$, in order to isolate the AgNPs. The nanoparticles were washed several times using deionized water, and then suspended in $95 \%$ ethanol prior to characterization.

\subsection{Characterization}

Optical absorbance of the synthesized silver nanoparticles was performed using a UV-visible spectrophotometer (Perkin-Elmer lambda 750 spectrophotometers) between the wavelengths of 300 and $900 \mathrm{~nm}$ at a resolution of 1 $\mathrm{nm}$. The reaction mixture was first diluted 5 times with distilled water and used for UV-visible analysis. Transmission electron microscopy (TEM) was performed to analysis the shape and size of the AgNPs using the JEOL TEM 100 CXII (Electron Microscope Unit, Assiut University, Egypt). Further, the formation of silver nanoparticles was checked by X-ray diffraction technique using an X-ray diffract meter (Shimadzu XD-3A).

\subsection{Plant Materials}

Wheat (Triticum aestivum L.) cultivar Seds12 and tomato (Solanum lycopersicum L.) cultivar VF 145B were used as the test plants to investigate the toxic effects of biosynthesized AgNPs. Seeds/Grains were surface sterilized with $5 \%$ sodium hypochlorite solution for $10 \mathrm{~min}$. and then rinsed several with sterilized distilled water.

\subsection{The Effects of AgNPs on Seedling Growth of Wheat}

Two sets grains were soaked in $100 \mathrm{~mL}$ of either $100 \mathrm{mg} / \mathrm{L}$ of AgNPs or distilled water (for control, without AgNPs) for $2 \mathrm{~h}$. Twenty grains were cultivated in Petri dish containing $10 \mathrm{~mL}$ distilled water over sterilized filter paper and incubated at $25{ }^{\circ} \mathrm{C}$ for 10 days. The germination rate (\%) was calculated as the proportion of the germinated grains to total number of grains (20 grains). The seedling emergence was observed periodically, 
length, dry weight, pigment fractions, soluble proteins and some antioxidant enzymes were measured after 10 days.

\subsection{The Effects of AgNPs on Vegetative Growth of Wheat and Tomato Plants}

Seeds of tomato and wheat grains were surface sterilized as above mentioned, then soaked in the biosynthesized AgNPs solution (100 mg/L) for $2 \mathrm{~h}$. Seeds/grains were sowed in pots filled with $2 \mathrm{~kg}$ mixed sieved air-dried clay and sand soil (2:1) then, irrigated with distilled water and kept at approximately $100 \%$ of the field capacity and let grown in an outdoor greenhouse at the Faculty of Science, Assiut University (Egypt). At the end of the experimental period (35 days) shoots and roots were harvested, their lengths and dry weights were recorded. Some leaves were freshly frozen in liquid nitrogen and stored at $-80^{\circ} \mathrm{C}$ for analysis the activity of some selected antioxidants enzymes (Catalase and Peroxidase) and MDA.

\subsubsection{Determination of Photosynthetic Pigments}

The pigment fractions (chlorophyll a, chlorophyll $b$ and carotenoids) were estimated in $95 \%$ ethanol extracts at $60{ }^{\circ} \mathrm{C}$ following the spectrophotometric method (Unico UV-21 00 spectrophotometer) recommended by Lichtenthaler et al. (1987).

\subsubsection{Determination of Soluble Proteins}

Protein concentration of tomato and wheat leaves extract was determined by the method of Lowery et al. (1951) using bovine serum albumin (BSA) as a standard curve.

\subsubsection{Determination of Lipid Peroxidation (MDA)}

Lipid peroxidation was determined by measuring malondialdehyde (MDA) formation using the thiobarbituric acid (TBA) reaction (MadhavaRao \& Stresty, 2000). Fresh tissue $(0.5 \mathrm{~g})$ was homogenized in $5 \mathrm{~mL}$ of $0.1 \%$ trichloroacetic acid (TCA). The homogenate was centrifuged at $10,000 \mathrm{rpm}$ for $10 \mathrm{~min}$. and $4 \mathrm{~mL}$ of $20 \%$ TCA containing TBA $0.5 \%$ was added to $1 \mathrm{~mL}$ of supernatant. The mixture was heated at $95{ }^{\circ} \mathrm{C}$ for $30 \mathrm{~min}$. and quickly cooled on ice, then centrifuged at 10,000 rpm for $15 \mathrm{~min}$., and the absorbance of the supernatant at 532 and $600 \mathrm{~nm}$, were read. After subtracting the non-specific absorbance at $600 \mathrm{~nm}$, the MDA concentration was determined by its extinction coefficient of $155 \mathrm{mM} / \mathrm{cm}$.

\subsubsection{Preparation of Enzyme Extract and Assay of Enzyme Activity}

Leaf tissue sample $(0.5 \mathrm{~g})$ was ground to a fine powder in liquid $\mathrm{N}_{2}$ and then homogenized in $5 \mathrm{~mL}$ of $100 \mathrm{mM}$ potassium phosphate buffer $(\mathrm{pH}$ 7.8) containing $0.1 \mathrm{~g}$ Ethylenediaminetetraacetic acid (EDTA) and $0.1 \mathrm{~g}$ polyvinylpyrrolidone (PVP). The homogenate was centrifuged at $18000 \mathrm{rpm}$ for $10 \mathrm{~min}$. at $4{ }^{\circ} \mathrm{C}$ and the supernatant was collected and used for the assays of catalase and guaiacol peroxidase. Colorimetric measurements of enzyme activities were made at $20^{\circ} \mathrm{C}$ using a Unico UV-2100 spectrophotometer. The specific activity of the enzymes was expressed as $\mathrm{mM} / \mathrm{min} / \mathrm{mg}$ protein.

1) Guaiacum Peroxidase (EC 1.11.1.7)

Guaiacum peroxidase (POD) activity was measured spectrophotometrically by following the method of Zaharieva et al. (1999). The formation of tetraguaiacol was measured at $470 \mathrm{~nm}$.

2) Catalase (EC 1.11.1.6)

Catalase (CAT) activity was assayed by following the consumption of $\mathrm{H}_{2} \mathrm{O}_{2}$ for $1 \mathrm{~min}$ (Abei, 1984). The change in absorbance at $240 \mathrm{~nm}$ was determined to calculate the specific activity.

\subsection{Statistical Analysis}

All data obtained were subjected to one-way analysis of variance (ANOVA), using the SPSS statistical package. For comparison of the means, the Duncan's multiple range tests $(\mathrm{p} \leq 0.05)$ were used.

\section{Results and Discussion}

\subsection{Synthesis of AgNPs and Its Characterization}

The feature of using plants for the synthesis of silver nanoparticle is that are easily available and safe to handle and possess a broad variability of metabolites that may help in reduction of silver nitrate. The leaf extract of rosemary (Rosmarinus officinalis) was found to be reducing and stabilizing agents for the green synthesis of AgNPs. Rapid appearance of a yellowish-brown colour in the reaction mixture as a result of surface plasmon, suggested the formation of colloidal AgNPs. The colour noted by visual observation increased in intensity giving brown colour after $24 \mathrm{~h}$ of incubation and hence confirmed the completion of reaction between leaf extract and $\mathrm{AgNO}_{3}$. Similar changes in colour have also been observed in previous studies and hence confirmed the 
completion of reaction between leaf extract and $\mathrm{AgNO}_{3}$ (Lalitha et al., 2013).

The AgNPs formation by reducing silver ions was investigated by UV-Vis spectroscopy. The UV-Visible absorption spectra of the aqueous solution of the biosynthesized AgNPs was measured in the 300-900 nm. Figure 1 shows broad absorption band located around $427 \mathrm{~nm}$. This beak, due to the surface plasmon resonance typical of silver nanoparticles and indicates that the particles were well dispersed without aggregation (Singhal et al., 2011).

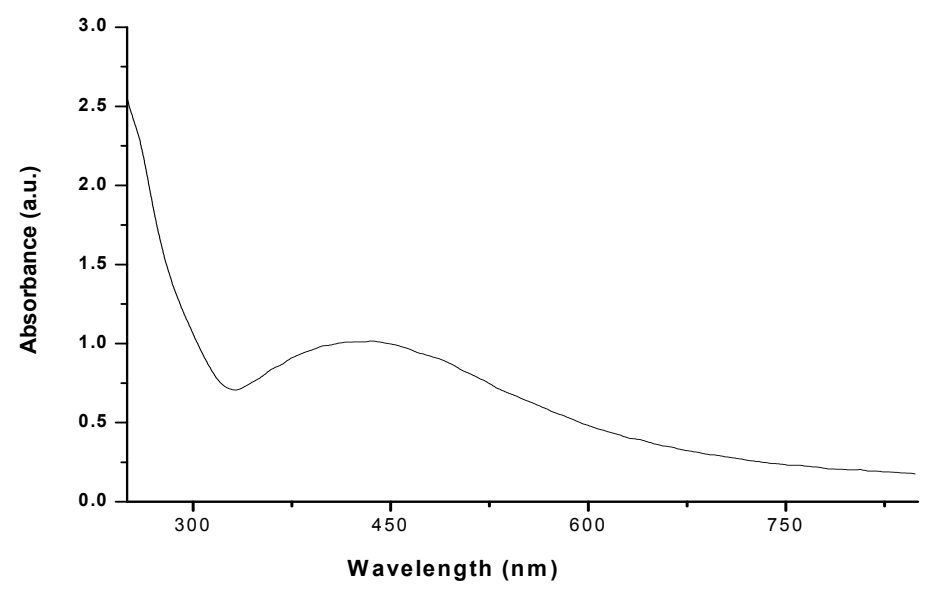

Figure 1. UV-Visible absorption spectra of AgNPs synthesized by rosemary leaf extract

TEM was used to investigate the shape and size distribution of AgNPs synthesized by the reduction of $\mathrm{Ag}^{+}$using rosemary leaf extract. The TEM images clearly reveal synthesis of spherical and polydispersive silver nanoparticles (Figure 2). The average size of biosynthesized nanoparticles was found to be around $17 \mathrm{~nm}$.

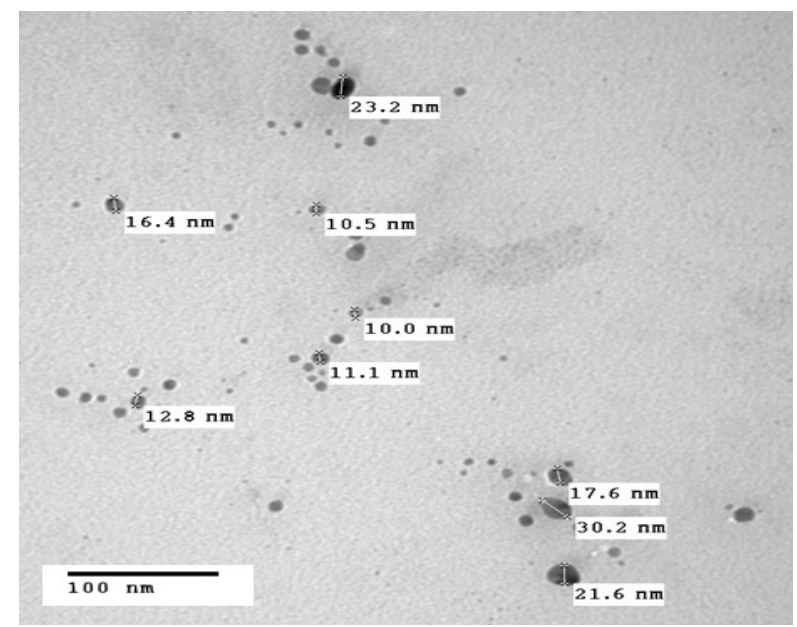

Figure 2. Transmission electron microscopy (TEM) image of silver nanoparticles (AgNPs) synthesized by rosemary leaf extract. Distribution of particles size was estimated to be around $17 \mathrm{~nm}$

The X-ray diffraction (XRD) analysis of AgNPs was confirmed the presence of silver in the sample again. The XRD pattern of dry powder of Ag nanoparticles shows clear diffraction line at low angles i.e., $10-80^{\circ}$ (Figure 3 ). The XRD graph shows intense peaks of silver at $2 \theta$ values equal to $37.84^{\circ}, 43.82^{\circ}, 64.21^{\circ}, 77.21^{\circ}$ due to reflection from the crystallographic (111), (200), (220), and (311) planes of face-centered cubic silver, respectively. The obtained data was matched with the Joint Committee on Powder Diffraction Standards (JCPDS files number 03-0921). 


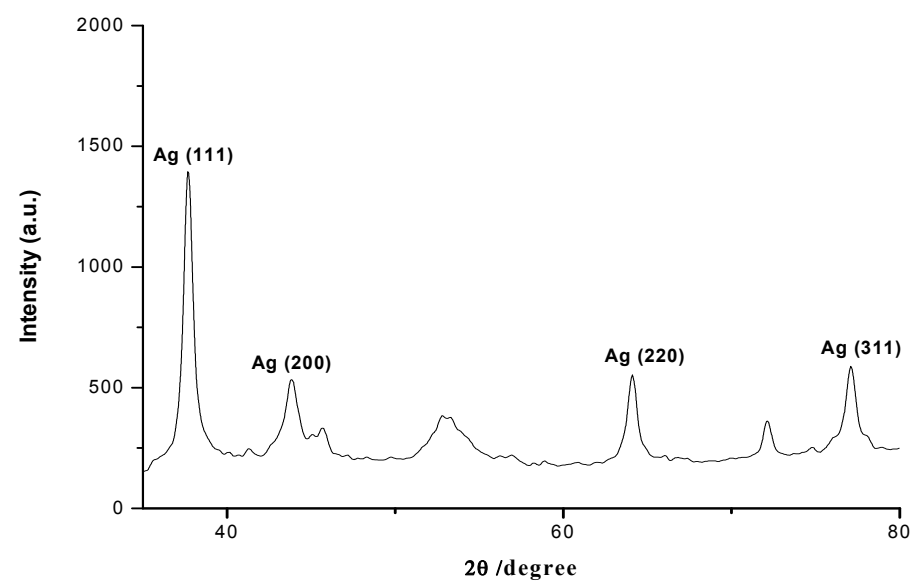

Figure 3. X-ray diffraction (XRD) pattern of crystalline silver nanoparticles synthesized by rosemary leaf extract

\subsection{The Effects of AgNPs on Seedling Growth of Wheat}

Application of nanotechnology is now widely distributed throughout life, and especially in agricultural systems. Nanoparticles, because of their physicochemical characteristics, are among the potential candidates for modulating the redox status and changing the growth, performance, and quality of plants (Mukherjee \& Mahapatra, 2010).

Phytotoxicity of higher plants should be investigated in order to develop a comprehensive toxicity profile for nanoparticles. Seed germination and root elongation is a rapid and widely used acute phytotoxicity test owing to sensitivity, simplicity, low cost and suitability for unstable chemicals (Abdel-Azeem \& Elsayed, 2013). However, standard phytotoxicity tests such as germination and root elongation may not sensitive enough or appropriate when evaluating nanoparticle toxicity to terrestrial plant species.

The biosynthesized AgNPs was applied for study its effects on wheat germination and seedling growth. Germination of wheat control grains was 57.5\%. However, germination of grains soaked with AgNPs (48\%) was not statistically significant (Table 1). Exposure of wheat grains to AgNPs affected the seedling growth. Meanwhile, the seedling length was significantly increased (125.7\%) relative to control. Mushtaq (2011) observed that the inhibitory effect of nanoparticles-exposure on seed germination of cucumber plants. Vannini et al. (2014) reported that the treatment with $10 \mathrm{mg} / \mathrm{L}$ PVP-AgNPs had a toxic effect on the early growth of wheat seedlings. Also Mazumdar and Ahmed (2011) observed that higher concentrations (1000 mg/mL) of chemically synthesized AgNPs are toxic to the seedlings of Oryza sativa in Hoagland's nutrient solution.

Data in Table 1 shows that seedling dry biomass was inhibited with soaking of wheat grains in AgNPs, while pigment fractions (chl.a, chl.b, caroteinoids) contents increased. Higher chlorophyll accumulation may be due to the complementary effect of other inherent nutrients like magnesium, iron and sulfur (Mohmoodzadeh et al., 2013). Similar results were observed by Zheng et al. (2005) when Spinacia oleracea seeds were treated with nanoscale $\mathrm{TiO}_{2}$ particles.

Table 1. The effects of $2 \mathrm{~h}$. Wheat grains soaking in AgNPs on germination and some growth parameters

\begin{tabular}{|c|c|c|c|c|c|c|c|c|c|}
\hline \multirow{2}{*}{ Treatment } & \multirow{2}{*}{$\begin{array}{l}\text { Germination } \\
(\%)\end{array}$} & \multirow{2}{*}{$\begin{array}{l}\text { Length } \\
(\mathrm{cm})\end{array}$} & \multirow{2}{*}{$\begin{array}{l}\text { Dry weight } \\
\text { (g/plant) }\end{array}$} & \multicolumn{3}{|c|}{$\begin{array}{l}\text { Photosynthetic pigments } \\
\qquad(\mathrm{mg} / \mathrm{g} \mathrm{FW})\end{array}$} & \multicolumn{2}{|c|}{$\begin{array}{c}\text { Antioxidant Enzymes } \\
\text { (specific activity) }\end{array}$} & \multirow{2}{*}{$\begin{array}{l}\text { Soluble protein } \\
(\mathrm{mg} / \mathrm{g} \mathrm{DW})\end{array}$} \\
\hline & & & & Chl.a & Chl.b & Caroteinoids & Catalase & Peroxidase & \\
\hline Control & $57.5 \pm 3.67^{\mathrm{a}}$ & $26.16 \pm 0.96^{\mathrm{a}}$ & $0.028 \pm 0.002^{\mathrm{a}}$ & $0.52 \pm 0.01^{\mathrm{a}}$ & $0.102 \pm 0.001^{\mathrm{a}}$ & $0.201 \pm 0.004^{\mathrm{a}}$ & $0.18 \pm 0.02^{\mathrm{a}}$ & $1.71 \pm 0.16^{\mathrm{a}}$ & $306.11 \pm 7.37^{\mathrm{b}}$ \\
\hline Ag NPs & $48 \pm 3.16^{\mathrm{a}}$ & $32.88 \pm 0.30^{\mathrm{b}}$ & $0.026 \pm 0.001^{\mathrm{a}}$ & $0.67 \pm 0.07^{\mathrm{a}}$ & $0.17 \pm 0.06^{\mathrm{a}}$ & $0.26 \pm 0.018^{b}$ & $0.15 \pm 0.08^{\mathrm{a}}$ & $1.61 \pm 0.13^{\mathrm{a}}$ & $279.69 \pm 6.96^{\mathrm{a}}$ \\
\hline
\end{tabular}

Note. Data are means of three replicates (+SE). Different letters are, significantly different at $P \leq 0.05$.

The rosemary biosynthesized AgNPs induced significant inhibitory effect on soluble proteins accumulation in wheat seedling. The AgNPs did not show any significant effect on both catalase and peroxidase enzymes (Table 1). The biosynthesized AgNPs showed a significant effect on Bacopa monnieri seed germination, induced the 
synthesis of protein, carbohydrate and decreased the total phenol content, catalase and peroxidase activities (Krishnaraj et al., 2012).

\subsection{The Effects of AgNPs on Vegetative Growth of Tomato and Wheat Plants}

Treatment of wheat grains by soaking in $100 \mathrm{mg} / \mathrm{L}$ of AgNPs and let to grow for 35 days (vegetative stage) induced decreasing in shoot and root lengths. The retardation in length for shoots and roots were 13.77 and 26.39\%, respectively in relative to its control (Figure 4). On the other hand AgNPs supplement to tomato induced stimulation in shoot length (30.82\%), but in its root less retardation (7.30\%). Salama (2012) reported that the AgNPs concentration of 20, 40 and $60 \mathrm{ppm}$ showed statistically significant stimulation on shoot and root elongation of the tested plants (common bean and corn) but concentration of 80 and $100 \mathrm{ppm}$ showed statistically significant inhibition on shoot and root elongation. The reduction in shoot and root lengths at higher doses may be attributed to toxic level of nanoparticles. AgNPs have both positive and negative effect on root elongation depending on the plants species (Gruyer et al., 2013). Exposure of tomato seeds to AgNPs caused a significant reduction in dry weight of both shoots and roots system. Meanwhile, exposure of wheat seeds with AgNPs induced non-significant increase in shoots dry weight, while roots exhibited non-significant inhibition (Figure 5). It was earlier reported that reduction in growth parameter is due to increase silver uptake by plants (Harris et al., 2008).

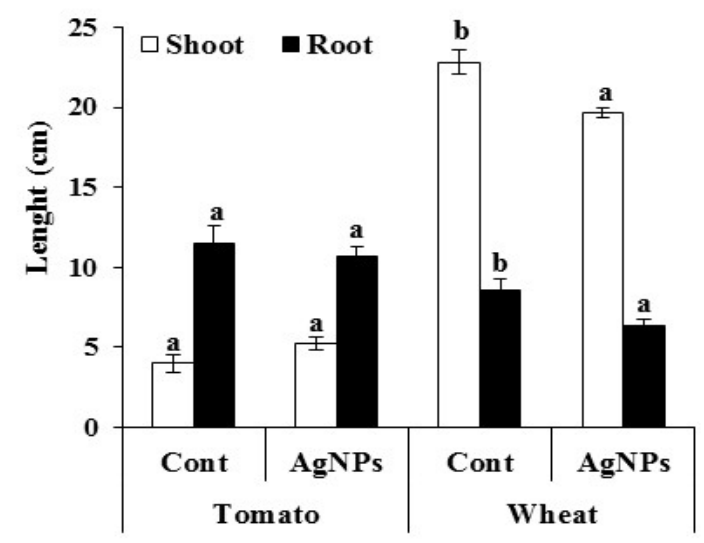

Figure 4. Length $(\mathrm{cm})$ of tomato and wheat plants (35-days) as affected by seed soaking in biosynthesized AgNPs

Note. Data are means of three replicates $( \pm \mathrm{SE})$. Different letters are, significantly different at $P \leq 0.05$.

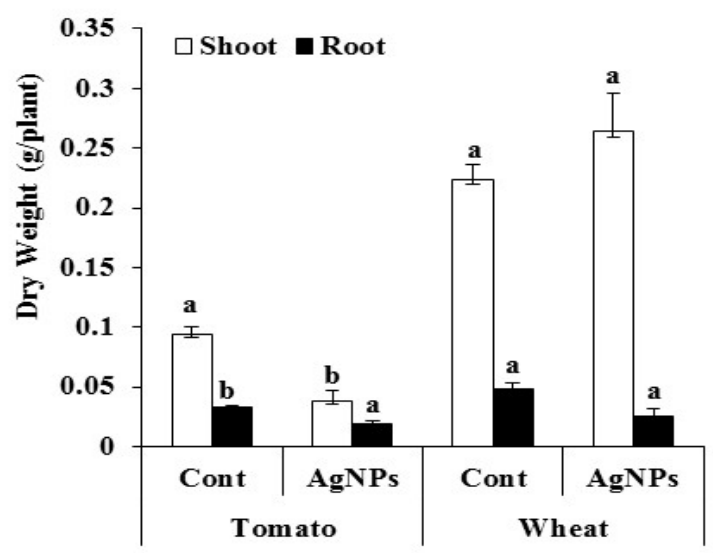

Figure 5. Dry weight (g/plant) of tomato and wheat plants (35-days) as affected by seed soaking in biosynthesized AgNPs

Note. Data are means of three replicates $( \pm \mathrm{SE})$. Different letters are, significantly different at $P \leq 0.05$.

Qian et al. (2013) reported the inhibitory effect of AgNPs on both root elongation and growth of the terrestrial 
plant Arabidopsis thaliana and mentioned that AgNPs exhibited their inhibitory action on growth of plants in a concentration dependent manner, being more toxic in the high concentration than in low concentration.

AgNPs treatments induced a significant stimulation in pigment fractions contents (Chl. b and Caroteinoids) of tomato plant except Chl.a which exhibited non-significant increasing (Figure 6). All pigment fractions in wheat plant were no significantly enhanced with supplemented with AgNPs in relative to control (Figure 6). This agree with Pandey et al. (2014) who noticed that chlorophyll content increased with increasing concentration of AgNPs. It was also reported that AgNPs could significantly promote photosynthesis and is closely related to the change of nitrogen metabolism. Racuciu and Creange (2007) reported that chlorophyll content of maize plants was found to be increased by low concentration $(10-50 \mu \mathrm{l} / \mathrm{L})$ while it was found to be inhibited by higher concentrations of magnetic nanoparticle. Increase in light harvesting complexes (LHC II) content help to promotes energy transfer and oxygen evolutions in photosystem II in spinach (Su et al., 2009). It was also reported that increase in Hill reaction and activity on chloroplasts by nano- $\mathrm{TiO}_{2}$ resulted in an acceleration of FeCy reduction and oxygen evolution in Spinacia oleracea (Hong et al., 2005).

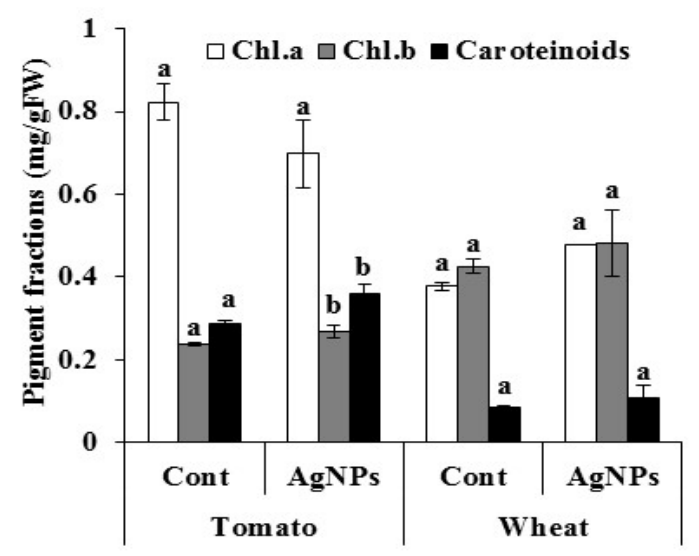

Figure 6. Photosynthetic pigment fractions (mg/g FW) of tomato and wheat plants (35-days) as affected by seed soaking in biosynthesized AgNPs

Note. Data are means of three replicates $( \pm \mathrm{SE})$. Different letters are, significantly different at $P \leq 0.05$.

AgNPs induced significant accumulation of soluble proteins in tomato leaves, but induced non-significant inhibition in wheat leaves (Figure 7). Salama (2012) reported that application of AgNPs at the concentration of 20, 40 and 60 ppm caused an increase in protein content of the two tested crop plants. The increase in protein at certain concentration suggests the optimum dose limit for the growth of common bean and corn plants. However, the decrease in protein beyond this concentration suggests the toxic effect of AgNPs. Soluble protein was also strong relative to the content of chlorophyll of plant leaf (Ren et al., 2011). With the increase of chlorophyll content, photosynthesis of plants increases, resulting in the accumulation of soluble protein. Najafi et al. (2014) reported that silver nanoparticles improved protein rate of Phaseolus vulgaris seedling. 


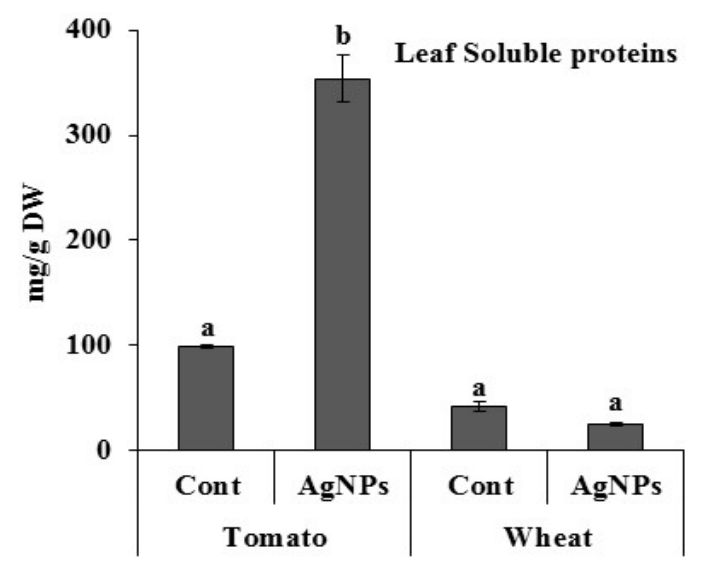

Figure 7. Soluble proteins (mg/g DW) in leaves of tomato and wheat plants (35-days) as affected by seed soaking in biosynthesized AgNPs

Note. Data are means of three replicates $( \pm \mathrm{SE})$. Different letters are, significantly different at $P \leq 0.05$.

Data in Figure 8 reveal that silver nanoparticles induced non-significant stimulation of lipid peroxidtion in leaves and roots of tomato and wheat in relative to control, except in wheat roots which exhibited a significant increasing. Lu et al. (2002) reported that N-Ag treated plants showed an efficient cellular electron exchange mechanism, which arrest electron leakage, reducing the ROS production and MDA levels. An increase in membrane lipid peroxidation has been associated with damage provoked by a variety of environmental stresses and is the most widely measured indicator of oxidative damage due to stress (Bemani et al., 2012). AgNPs damaged membranes of plants and the level of membrane lipid peroxidation significantly increased along with the increase of AgNPs concentration (Ghanati \& Bakhtiarian, 2013).

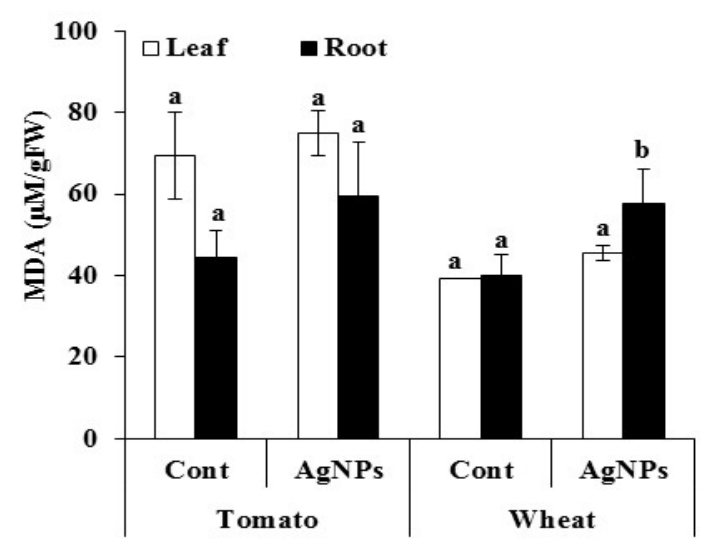

Figure 8. Lipid peroxidation MDA ( $\mu \mathrm{M} / \mathrm{g} \mathrm{FW})$ in leaves and roots of tomato and wheat plants (35-days) as affected by seed soaking in biosynthesized AgNPs

Note. Data are means of three replicates $( \pm \mathrm{SE})$. Different letters are, significantly different at $P \leq 0.05$.

There was noticeably difference in antioxidant enzymes activities among the employed plants treatments. Silver nanoparticles induced a non significant increasing in catalase activity of tomato plant, while wheat plant exhibited the opposite trend, which significantly inhibited (Figure 9). It is worse to mention that the maximum value of peroxidase activity was observed in tomato plant treated with silver nanoparticles $(245.218 \%)$ in relative to its control. On the other hand peroxidase activity was significantly inhibited in wheat plant (Figure 9). Krishnaraj et al. (2012) reported that high activity of CAT and POX were recorded from leaf samples of plants subjected to nano silver treatment, implying less ROS formation, resulting in less toxicity to the plants. They also reported that CAT and POX are enzymes that plays a major role in ensuring protection against oxidative damage in plants exposed to nanosilver particles treatments. Lei et al. (2008) stated that nanoparticles $\left(\mathrm{TiO}_{2}\right)$ decreased oxidative damage in spinach chloroplast by increasing APX, SOD, POD, and CAT activity. Farrag 
(2015) reported that catalase activity increased with treatment of test plant by AgNPs.
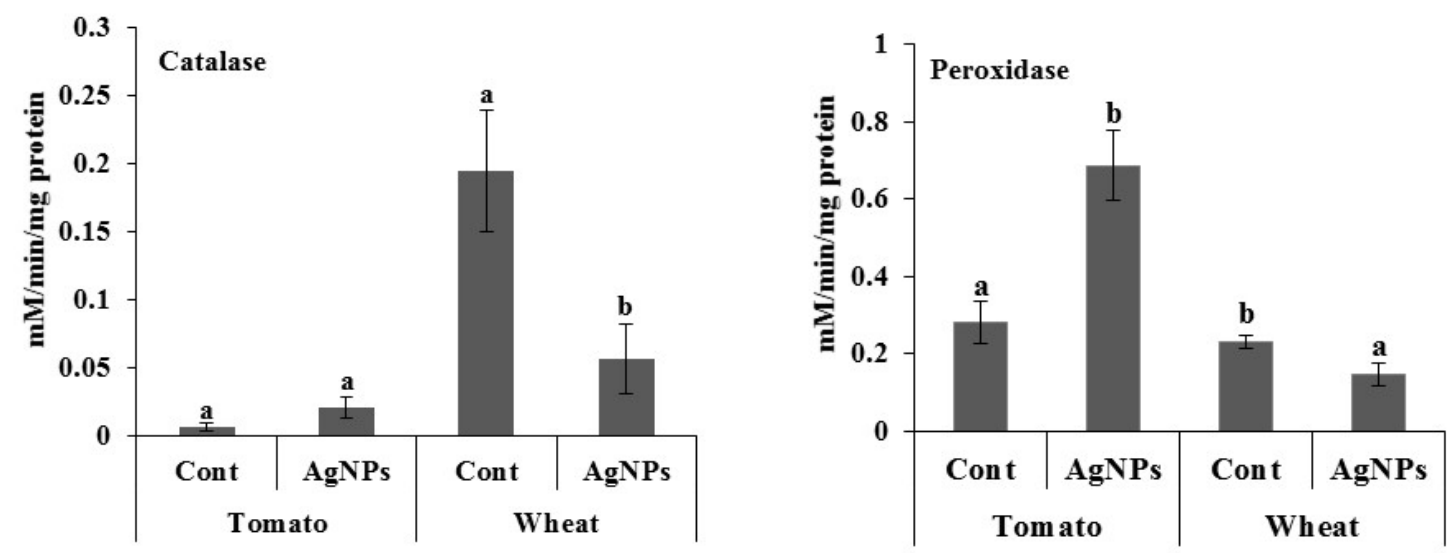

Figure 9. Catalase and peroxidase activities [specific activity ( $\mathrm{mM} / \mathrm{min} / \mathrm{mg}$ protein)] in leaves of tomato and wheat plants (35-days) as affected by seed soaking in biosynthesized AgNPs

Note. Data are means of three replicates $( \pm \mathrm{SE})$. Different letters are, significantly different at $P \leq 0.05$.

\section{Conclusion}

In conclusion, green synthesis of silver nanoparticles by rosemary leaves extract is inexpensive and ecofriendly. The biosynthesized AgNPs has a noticeable stress effect on tomato plant as reduced chlorophyll a and dry weight and stimulate the activity of peroxidase and MDA. Catalase and peroxidase specific activity reduced significantly in treated wheat seedling. So, the biosynthesized AgNPs has a positive and negative effect on wheat seedling and vegetative growth of tomato and wheat plants.

\section{References}

Abdel-Azeem, E. A., \& Elsayed, B. A. (2013). Phytotoxicity of silver nanoparticles on Vicia faba seedlings. New York Science Journal, 6, 184-156.

Aebi, H. (1984). Catalase. Methods in Enzymology (1st ed., Vol. 105, pp. 121-126). Academic Press, Orlando, USA. http://dx.doi.org/10.1016/s0076-6879(84)05016-3

Bemani, E., Ghanati, F., Boroujeni, L. Y., \& Khatami, F. (2012). Antioxidant activity, total phenolics and taxol contents response of hazel (Corylus avellana L.) cells to benzoic acid and cinnamic acid, Notulae Botanicae Horti Agrobotanici Cluj-Napoca, 40, 69-73.

Choi, O., Deng K. K., Kim, N. J., Ross, L., Surampalli, R. Y., \& Hu, Z. (2008). The inhibitory effects of silver nanoparticles, silver ions, and silver chloride colloids on microbial growth. Water Research, 42, 3066-3074. http://dx.doi.org/10.1016/2008.02.021

Farrag, H. F. (2015). Evaluation of the Growth Responses of Lemna gibba L. (Duckweed) Exposed to Silver and Zinc Oxide Nanoparticles. World Applied Science Journal, 33, 190-202. http://dx.doi.org/10.1016/j.scitotenv.2013.02.059

Georgios, A. S., \& Sotiris, E. P. (2010). Antibacterial activity of nanosilver ions and particles. Environmental Science Technology, 44, 5649-5654. http://dx.doi.org/10.1021/es101072s

Ghanati, F., \& Bakhtiarian, S. (2013). Changes of natural compounds of Artemisia annua L. by methyl jasmonate and silver nanoparticles. Advances in Environmental Biology, 7, 2251-2258.

Gruyer, N., Dorais, M., Bastien, C., Dassylva, N., \&Triffault-Bouchet, G. (2013). Interaction between sliver nanoparticles and plant growth. International symposium on new technologies for environment control, energy-saving and crop production in greenhouse and plant factory - greensys, Jeju, Korea (pp. 6-11). http://dx.doi.org/10.17660/actahortic.2014.1037.105

Harris, A. T., \& Bali, R. (2008). On the formation and extent of uptake of silver nanoparticles by live plants. Journal of Nanoparticle Research, 10, 691-695. http://dx.doi.org/10.1007/s11051-007-9288-5

Hong, F., Zhou, J., Liu, C., Yang, F., Wu, C., Zheng, L., \& Yang, P. (2005). Effect of nano-TiO ${ }_{2}$ on 
photochemical reaction of chloroplasts of spinach. Biological Trace Element Research, 105, 269-279. http://dx.doi.org/10.1385/105:1-3:269

Kim, S. J., Kuk, E., Yu, N. K., Kim, J. H., Park, J. S., Lee, J. H., ... Cho, M. H. (2007). Antimicrobial effects of silver nanoparticles. Nanomedicine: Nanotechnology, Biology, and Medicine, 3, http://dx.doi.org/10.4172/scientificreports.538

Krishnaraj, C., Jagan, E. G., Ramachandran, R., Abirami, S. M., Mohan, N., \& Kalaichelvan, P. T. (2012). Effect of biologically synthesized silver nanoparticles on Bacopa monnieri (Linn.) Wettst. Plant growth metabolism. Process Biochemistry, 47, 651-658. http://dx.doi.org/10.1016/j.procbio.2012.01.006

Lalitha, A., Subbaiya, R., \& Ponmurugan, P. (2013). Green synthesis of silver nanoparticles from leaf extract Azhadirachta indica and to study its anti-bacterial and antioxidant property. International Journal of Current Microbiology and Appied Sciences, 2, 228-235.

Lei, Z., Mingyu, S., Xiao, W., Chao, L., Chunxiang, Q., Liang, C., ... Hao, H. (2008). Antioxidant stress is promoted by nano-anatase in spinach chloroplasts under UV-B radiation. Biological Trace Element Research, 121, 69-79. http://dx.doi.org/10.1007/s12011-007-8028-0

Levard, C., Hotze, E. M., Lowry, V. G., \& Brown, E. G. (2012). Environmental Transformations of Silver Nanoparticles: Impact on Stability and Toxicity. Environmental Science \& Technology, 46, 6900-6914. http://dx.doi.org/10.1021/es2037405

Lichtenthaler, H. K. (1987). Chlorophylls and carotenoids: Pigments of photosynthetic biomembranes. Methods in Enzymology, 148, 183-350. http://dx.doi.org/10.1016/0076-6879(87)48036-1

Lin, D., \& Xing, B. (2008). Root uptake and phytotoxicity of $\mathrm{ZnO}$ nanoparticles. Environmental Science \& Technology, 42, 5580-5585. http://dx.doi.org/10.1016/0076-6879(87)48036-1

Lowry, O. H., Rosebrough, N. J., Farr, A. L., \& Randall, R. J. (1951). Protein measurement with folin phenol reagent. The Journal of Biological Chemistry, 193, 265-275.

Lu, C. M., Zhang, C. Y., Wen, J. Q., \& Wu, G. R. (2002). Research on the effect of nanometer materials on germination and growth enhancement of Glycinemax and its mechanism. Soybean Science, 21, 68-171.

Madhava Rao, K. V., \& Sresty, T. V. S. (2000). Antioxidative parameters in the seedlings of pigeonpea (Cajanus cajan L. Millspaugh) in response to $\mathrm{Zn}$ and $\mathrm{Ni}$ stresses. Plant Science, 157, 113-128. http://dx.doi.org/10.1016/s0168-9452(00)00273-9

Mahmoodzadeh, H., Aghili, R., \& Nabavi, M. (2013). Physiological effects of $\mathrm{TiO}_{2}$ nanoparticles on wheat (Triticum aestivum). Technical Journal of Engineering \& Applied Sciences, 3, 1365-1370.

Mazumdar, H., \& Ahmed, G. V. (2011). Phytotoxicity effect of silver nanoparticles on Oryza sativa. International Journal Chem Tech Research, 3, 1494-1500.

Mittal, A. K., Chisti, Y., \& Banerjee, U. C. (2013). Synthesis of metallic nanoparticles using plant extracts. Biotechnology Advances, 31, 346-356. http://dx.doi.org/10.1016/j.biotechadv.2013.01.003

Mukherjee, M., \& Mahapatra, A. (2010). On electron Effect of coinage metal nanoparticles and zwitterionic surfactant on reduction of $\left[\mathrm{Co}\left(\mathrm{NH}_{3}\right)_{5} \mathrm{Cl}\right]\left(\mathrm{NO}_{3}\right)_{2}$ by iron (II). Colloids and Surface, 368, 1-3. http://dx.doi.org/10.1016/j.colsurfa.2010.07.021

Mushtaq, Y. K. (2011). Effect of nanoscale $\mathrm{Fe}_{3} \mathrm{O}_{4}, \mathrm{TiO}_{2}$ and carbon particles on cucumber seed germination. Journal of Environmental Science and Health, 46, 1732-1735. http://dx.doi.org/10.1080/10934529.2011.633403

Najafi, S., Heidari, R., \& Jamei, R. (2014). Photosynthetic Characteristics, Membrane lipid levels and Protein content in the Phaseolus vulgaris L. (cv. Sadri) exposed to Magnetic Field and Silver Nanoparticles. Bulletin of Environment, Pharmacology and Life Sciences, 3, $72-76$.

Pandey, C., Khan, E., Mishra, A., Sardar, M., \& Gupta, M. (2014). Silver Nanoparticles and Its Effect on Seed Germination and Physiology in Brassica juncea L. (Indian mustard) Plant. Advanced Science Letters, 20, 1673-1676. http://dx.doi.org/10.1166/asl.2014.5518

Piccapietra, F., Allu'e, C. G., Sigg, L., \& Behra, R. (2012). Intracellular silver accumulation in Chlamydomonas reinhardtii upon exposure to carbonate coated silver nanoparticles and silver nitrate. Environmental Science and Technology, 46, 7390-7397. http://dx.doi.org/10.1021/es300734m

Qian, H., Peng, X., Han, X., Ren, J., Sun, L., \& Fu, Z. (2013). Comparison of the toxicity of silver nanoparticles 
and silver ions on the growth of terrestrial plant model Arabidopsis thaliana. Journal of Environmental Sciences, 25, 1947-1955. http://dx.doi.org/10.1016/s1001-0742(12)60301-5

Racuciu, M., \& Creanga, D. E. (2007). TMA-OH Coated magnetic nanoparticles internalized in vegetal tissue. Romanian Journal Physics, 52, 395-402.

Remédios, C., Rosrio, F., \& Bastos, V, (2012). Environmental nanoparticles interactions with plants: morphological, physiological, and genotoxic aspects. Journal of Botany, 1-8 http://dx.doi.org/10.1155/2012/751686

Ren, H. X., Liu, L., Liu, C., He, S. Y., Huang, J., Li, L. J., ... Gu, N. (2011). Physiological Investigation of Magnetic Iron Oxide Nanoparticles towards Chinese Mung Bean. Journal of Biomedical Nanotechnology, 7, 677-684. http://dx.doi.org/10.1166/jbn.2011.1338

Salama, H. M. H. (2012). Effects of silver nanoparticles in some crop plants, common bean (Phaseolus vulgaris L.) and corn (Zea mays L.). International Research Journal of Biotechnology, 3,190-197.

Sharma, V., Shukla, R. K., Saxena, N., Parmar, D., Das, M., \& Dhawan, A. (2009). DNA damaging potential of zinc oxide nanoparticles in human epidermal cells. Toxicology Letters, 185, 211-218. http://dx.doi.org/10.1016/j.toxlet.2009.01.008

Singhal, G., Bhavesh, R., Kasariya, K., Sharma, A. R., \& Singh, R. P. (2011). Biosynthesis of silver nanoparticles using Ocimum sanctum (Tulsi) leaf extract and screening its antimicrobial activity. Journal of Nanoparticle Research, 13, 2981-2988. http://dx.doi.org/10.1007/s11051-010-0193-y

$\mathrm{Su}$, M., Hong, F., Liu, C., Wu, X., Liu, X., Chen, L., ... Li, Z. (2009). Effects of nano-anatase $\mathrm{TiO}_{2}$ on absorption, distribution of light and photo reduction activities of chloroplast membrane of spinach. Biological Trace Element. Research, 131(1), 101. http://dx.doi.org/10.1007/s12011-007-0006-z

Tamuly, C., Hazarika, M., Borah, S. C., Das, M. R., \& Boruah, M. P. (2013). In situ biosynthesis of Ag, Au and bimetallic nanoparticles using Piper pedicellatum C.DC: Green chemistry approach. Colloids and Surfaces B: Biointerfaces, 102, 627-634. http://dx.doi.org/10.1016/j.colsurfb.2012.09.007

Thuesombat, P., Hannongbua, S., Sanong, A., \& Chadchawan, S. (2014). Effect of silver nanoparticles on rice (Oryza sativa L. cv. KDML 105) seed germination and seedling growth. Ecotoxicology and Environmental Safety, 104, 302-309. http://dx.doi.org/10.1016/j.ecoenv.2014.03.022

Vannini, C., Domingoa, G., Onelli, E., De Mattia, F., Bruni, I., Marsonia, M., \& Bracale, M. (2014). Phytotoxic and genotoxic effects of silver nanoparticles exposure on germinating wheat seedlings. Journal of Plant Physiology, 171, 1142-1148. http://dx.doi.org/10.1016/j.jplph.2014.05.002

Yin, L., Colman, B. P., McGill, B. M., Wright, J. P., \& Bernhardt, E. S. (2012). Effects of silver nanoparticle exposure on germination and early growth of eleven wetland Plants. PLoS One, 7(10), e47674. http://dx.doi.org/10.1371/journal.pone.0047674

Zaharieva, T., Yamashita, K., \& Matsumoto, H. (1999). Iron deficiency induced changes in ascorbate content and enzyme activities related to ascorbate metabolism in cucumber roots. Plant and Cell Physiology, 40, 273-280. http://dx.doi.org/10.1093/oxfordjournals.pcp.a029538

Zheng, L., Hong, F., Lu, S., \& Liu, C. (2005). Effect of nano- $\mathrm{TiO}_{2}$ on strength of naturally aged seeds and growth of Spinach. Biological Trace Element Research, 105, 83-91. http://dx.doi.org/10.1385/bter:104:1:083

\section{Copyrights}

Copyright for this article is retained by the author(s), with first publication rights granted to the journal.

This is an open-access article distributed under the terms and conditions of the Creative Commons Attribution license (http://creativecommons.org/licenses/by/3.0/). 